\title{
Effect of L-thyroxin therapy on thyroid volume and carotid artery Intima-media thickness in the patients with subclinical hypothyroidism
}

Ilknur Ozturk Unsal*, Oya Topaloglu, Evrim Cakir, Nujen Colak Bozkurt, Basak Karbek, Askin Gungunes, Muyesser Sayki Arslan, Esra Tutal Akkaymak, Bekir Ucan, Taner Demirci, Melia Karakose, Mustafa Caliskan, Erman Cakal and Tuncay Delibasi

*Correspondence: Illknur_dr@yahoo.com

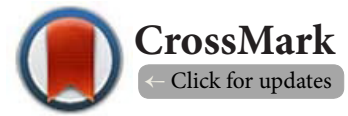

Department of Endocrinology and Metabolism, Diskapi Teaching and Research Hospital, Ankara, Turkey.

\begin{abstract}
Background: Subclinical hypothyroidism ( $\mathrm{SCH}$ ) is mild-to-moderate thyroid insufficiency that is characterized by thyrotropin (TSH) level higher than the upper limit despite normal serum free thyroxin (fT4) level. Likewise, $\mathrm{SCH}$ as well might be a risk factor for cardiovascular diseases. Some placebocontrolled studies showed beneficial effect of L-thyroxin replacement on the risk for early atherosclerosis and CVD in the patients with SCH.

Methods: Fifty-six patients presented to our clinic with subclinical hypothyroidism were included in the study. Forty-six healthy euthyroid subjects were included as the control group. Patients with fT4 $>0.61 \mathrm{ng} /$ $\mathrm{dl}$ and TSH>4.2 uIU/ml were considered as SCH. Serum LDL and HDL cholesterols, triglyceride level, thyroid antibodies (anti-TPOAb and anti-TgAb), and fasting plasma glucose levels of the patients and the control group were measured. Carotid artery intima-media thickness (CIMT) was measured via B-mode ultrasonography and thyroid volume was calculated. L-thyroxin replacement was commenced at a dose of 25-50 mcg/day. CIMT and thyroid volumes of the patients were reevaluated six months after they became euthyroid.
\end{abstract}

Results: A statistically significant difference $(\mathrm{p}<0.05)$ was found between the CIMT values before and after the L-thyroxin therapy in the $\mathrm{SCH}$ group. Pretreatment CIMT values were significantly higher than the post-treatment CIMT values $(\mathrm{p}=0.0001)$. There was significant difference also between the pre-treatment and post-treatment thyroid volumes in the $\mathrm{SCH}$ group $(\mathrm{p}<0.05)$.

Conclusion: The present study showed the reduction in CIMT with L-thyroxin therapy in the patients with subclinical hypothyroidism. Therefore, thyroid hormone replacement might help to slow down or prevent atherosclerosis in the subclinical hyperthyroidism as well.

Keywords: Subclinical hypothyroidism, intima-media thickness, cardiovascular disease, atherosclerosis

\section{Introduction}

Subclinical hypothyroidism $(\mathrm{SCH})$ is mild-to-moderate thyroid insufficiency that is characterized by thyrotropin (TSH) level higher than the upper limit despite normal serum free thyroxin (fT4) level [1]. The prevalence of $\mathrm{SCH}$ is $4-10 \%$ according to the epidemiological data obtained from large population-based trials [2-9]. In females, this rate notably increases after the age of 45 years [10]. In males, it is similar to females after the $6^{\text {th }}$ decade. Anti-thyroid antibodies are found positive in $80 \%$ of the patients with subclinical hypothyroidism and TSH level is less than $10 \mathrm{mIU} / \mathrm{L}[2]$.
The etiology of subclinical hypothyroidism is similar to that of manifest hypothyroidism, and autoimmune thyroid diseases are the most common causes $[1,11]$. On the other hand, it may develop as the consequence of treatments, such as radioactive iodine therapy and external radiotherapy top the head-neck region, that lead to thyroid tissue injury. Serum TSH level temporarily or permanently increases after subacute, postpartum and painless thyroiditis episodes. Actually, $17.6-30 \%$ of the cases with manifest hypothyroidism are diagnosed with subclinical hypothyroidism due to inadequate thyroid hormone replacement therapy [3,12]. Drugs such as

(C) 2014 Unsal et al; licensee Herbert Publications Ltd. This is an Open Access article distributed under the terms of Creative Commons Attribution License (http://creativecommons.org/licenses/by/3.0). This permits unrestricted use, distribution, and reproduction in any medium, provided the original work is properly cited. 
Unsal et al. Journal of Medical Disorders 2014,

http://www.hoajonline.com/journals/pdf/2053-3659-2-1.pdf

doi: 10.7243/2053-3659-2-1

tamoxifen, chemotherapy, compounds that include iodine, cytokines (particularly Interferon- $\alpha$ and $\beta$ ), amiodarone, lithium carbonate, aminoglutethimide, ethionamide, sulfonamides and sulfonylureas cause thyroid dysfunction [13-21]. Moreover, infiltrative diseases (Riedel's thyroiditis, amyloidosis, hemochromatosis, and cystinosis) and infectious diseases (Pneumocystis carinii infection and Kaposi's sarcoma in the patients with AIDS) of thyroid gland and TSH-receptor gene mutations as well may cause subclinical hypothyroidism $[13,22,23]$.

Subclinical hypothyroidism, as well as manifest hypothyroidism, may be a risk factor for cardiovascular diseases, but it is debatable. Various studies reported that there is no relation between subclinical hypothyroidism and cardiovascular risk $[\mathbf{2 4 , 2 5}$. Contrarily, a meta-analysis concluded that subclinical hypothyroidism is associated with coronary artery disease and atherosclerosis [26]. Some placebo-controlled studies demonstrated that levothyroxine replacement has favorable effect on early atherosclerosis and cardiovascular risk in the patients with subclinical hypothyroidism $[\mathbf{2 7 , 2 8}$. Measurement of the carotid artery intima-media thickness (C-IMT) via B-mode ultrasonography (Figure 1) provides easy evaluation of atherosclerosis.

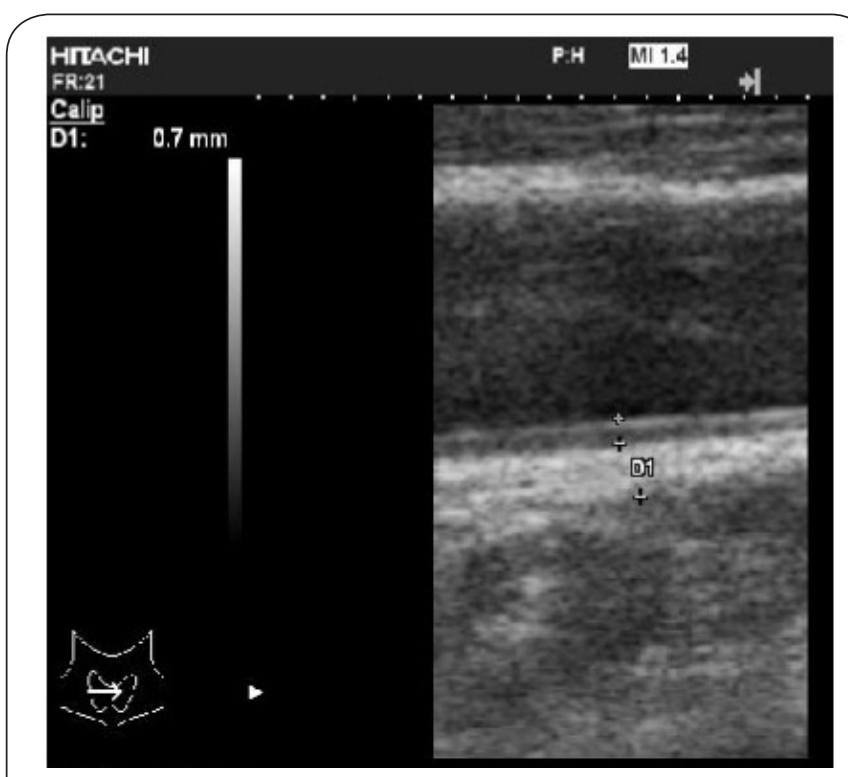

Figure 1. Measurement of carotid artery intima-media thickness by ultrasound.

The present study aimed to show the reduction in C-IMT and thyroid volume with L-thyroxin therapy in the patients with subclinical hypothyroidism.

\section{Materials and methods}

Fifty-six patients presented to our outpatient clinic with subclinical hypothyroidism were included in the study from our outpatient clinic. Forty-six healthy euthyroid subjects were included as the control group. Patients with normal serum free thyroxin and TSH $>4.2 \mathrm{ulU} / \mathrm{ml}$ were considered as $\mathrm{SCH}$. The protocol was approved by the local Ethics Committee and all the participants provided written informed consent.

We examined their physical examination, biochemical tests, and history of medications (Interferon- $\alpha$ and $\beta$, amiodarone, lithium carbonate, aminoglutethimide, ethionamide, statins, corticosteroids) or cardiovascular diseases (coronary artery disease, peripheral artery disease or stroke). The routine laboratory chemistry was normal in all participants.

L-thyroxin replacement was commenced at a dose of 25-50 $\mathrm{mcg} /$ day. The dosage taken was individualized for each patient and was given once a day before breakfast in the morning. CIMT and thyroid volumes of the patients were reevaluated six months after they became euthyroid.

Those participants who had previous thyroid disease, antithyroid medications, thyroid hormone treatment, thyroidectomy, radioiodine theraphy, and medications known to affect the lipid profile (e.g., statin), history of alcohol use, obesity, diabetes mellitus, arterial hypertension, liver, or renal diseases, were suffering from any cardiovascular disease were excluded from the study.

\section{Biochemical evaluation}

Serum free thyroxin (fT4), thyroid stimulating hormone (TSH), thyroid peroxidase anti-body (anti-TPO) and thyroglobulin anti-body (anti-Tg) were measured with chemiluminescence assay (Advia Centaur, Siemens Healthcare Diagnostics, USA) and specific electrochemiluminescence immunoassays (Elecsys 2010 Cobas, Roche Diagnostics, Mannheim, Germany). The levels of total-cholesterol, high density lipoprotein cholesterol $(\mathrm{HDL}-\mathrm{C})$, and triglyceride (TG) were determined with enzymatic colorimetric assays by spectrophotometry (BioSystems S.A., Barcelona, Spain). The low density lipoprotein cholesterol $(\mathrm{LDL}-\mathrm{C})$ level was calculated using the Friedewald formula. Serum glucose, high-density lipoprotein (HDL) cholesterol, and triglyceride levels were measured using commercial enzymatic kits.

\section{Thyroid volume (TV) and CIMT}

Thyroid volume was assessed using a high-resolution ultrasound machine with a 13 megahertz high-frequency linear transducer (Hitachi EUB $7000 \mathrm{HV}$ ). Thyroid volumes were calculated by multiplication of three diameters and the constant value $0.52[29,30]$.

Carotid artery intima-media thickness (CIMT) was measured via high-resolution B-Mode ultrasonography using a $13-\mathrm{MHz}$ linear probe (Hitachi EUB 7000 HV). Three arterial wall segments of the common carotid artery were measured bilaterally after imaging from a fixed lateral transducer angle and designated as mean CIMT. IMT was defined as the distance from the leading edge of the lumen intima-interface to the leading edge of the media-adventitia.

To avoid subjective error, both CIMT and thyroid volume 
Unsal et al. Journal of Medical Disorders 2014,

measurements were taken by the same person.

\section{Statistical analyses}

Data of the study were evaluated by SPSS 15.0 package program. Distribution of frequency and percentage of the data was demonstrated. After data normality test, difference between the groups was analyzed by Independent Samples t-test for the variables with normal distribution and by Mann Whitney U Test for the variables distributed not normally. Dependency between variables was analyzed using Chi-square test and the difference between initially and subsequently measured variables was analyzed using Wilcoxon Signed Rank test.

Level of significance for between group analyses was considered to be 0.05 and it was expressed that there is significant difference between the groups in case $p<0.05$, but there is no significant difference between the groups in case $p>0.05$.

\section{Results}

Serum TSH and HDL- cholesterol levels were significantly higher in SCH compared with healty control subject (Table 1).

Table 1. Baseline characteristics of the study population.

\begin{tabular}{llll}
\hline & $\begin{array}{l}\text { Euthyroid control } \\
(\mathbf{n = 4 6})\end{array}$ & $\begin{array}{l}\text { Subclinical } \\
\text { hypothyroidism } \\
(\mathbf{n = 5 6 )}\end{array}$ & $\boldsymbol{p}$ \\
\hline Age (year) & $36.07 \pm 10.580$ & $41.32 \pm 14.485$ & 0.037 \\
\hline Gender (\%) & & & \\
\hline Female & 54.35 & 91.07 & -- \\
Male & 45.65 & 8.93 & -- \\
\hline TSH (uIU/ml) & $1.65 \pm 0.913$ & $6.77 \pm 2.902$ & 0.000 \\
HDL-C (mg/dl) & $47.93 \pm 12.153$ & $53.76 \pm 12.071$ & 0.017 \\
LDL-C (mg/dl) & $111.72 \pm 28.141$ & $117.84 \pm 30.272$ & 0.297 \\
C-intima media & $0.5 \pm 0.086$ & $0.53 \pm 0.112$ & 0.115 \\
thickness (mm) & & & 0.167 \\
Thyroid volume (ml) & $13.07 \pm 6.320$ & $11.48 \pm 4.646$ & \\
\hline
\end{tabular}

Data are the mean \pm SD

Of the patients in the SCH group, 51(91.1\%) were female and $5(8.9 \%)$ were male, whereas the control group comprised 25 (54.3\%) females and 21(45.7\%) males. A statistically significant difference $(p<0.05)$ was found between the CIMT values before and after the L-thyroxin therapy in the $\mathrm{SCH}$ group. Pretreatment CIMT values were significantly higher than the post-treatment CIMT values. There was significant difference also between the pre-treatment and post-treatment thyroid volumes in the SCH group $(p<0.05)$; pretreatment thyroid volumes were significantly higher than the post-treatment thyroid volumes (Table 2). No significant difference was determined between the $\mathrm{SCH}$ and the control group in terms of pretreatment CIMT values ( $p>0.05$ ). When the $\mathrm{SCH}$ group was divided into two
Table 2. Before or after Levothyroxine theraphy.

\begin{tabular}{lllc}
\hline & Before LT4 & After LT4 & $\boldsymbol{p}$ \\
\hline TSH (uIU/ml) & $6.773 \pm 2.902$ & $2.734 \pm 1.166$ & 0.0001 \\
$\begin{array}{l}\text { C-intima media } \\
\text { thickness (mm) }\end{array}$ & $0.533 \pm 0.112$ & $0.507 \pm 0.126$ & 0.0001 \\
Thyroid volume (ml) & $11.484 \pm 4.646$ & $9.294 \pm 3.906$ & 0.0001 \\
\hline
\end{tabular}

Data are the mean \pm SD

as TSH level less than $7 \mathrm{ulU} / \mathrm{ml}(\mathrm{n}=39)$ and TSH level higher than $7 \mathrm{ulU} / \mathrm{ml}(\mathrm{n}=17)$, no significant difference was found between the groups in terms of CIMT values and thyroid volumes ( $p>0.05)$.

\section{Discussion}

Many studies have examined the relationship between subclinical hypothyroidism and cardiovascular disease. However, contradictory results have been obtained in the studies and whilst some studies determined an increase in cardiovascular risk with subclinical hypothyroidism [31-33], some studies failed to demonstrate such a relation [24,25,34]. For example, Rotterdam study demonstrated that myocardial infarction and aortic calcification are associated with $\mathrm{SCH}$ [31]. Contrarily, Wickham study observed no increase in cardiac mortality over the course of 20-year follow-up [35]. In addition, numerous meta-analyses and observational studies determined relation between coronary artery disease and $\mathrm{SCH}$ [36-38]. However, some recent observational studies demonstrated no relation between cardiovascular events, mortality and unrecognized SCH [24]. Analysis of 7 cohort studies demonstrated increase in all-cause mortality in $\mathrm{SCH}$, particularly in the presence of comorbidities, as compared to the euthyroid individuals [39]. Another meta-analysis comprising 15 studies revealed an increase in the incidence and prevalence of cardiovascular mortality in young population [26].

Studies demonstrated that, thyroid hormones inhibit collagen-stimulated platelet aggregation and inhibition is not observed in the absence of thyroid hormone deficiency [40]. Hypothyroidism is accompanied by endothelial dysfunction and impaired nitric oxide production, which are also encountered in the early stage of atherosclerosis [41-44].

Carotid artery intima-media thickness is an important marker for atherosclerosis stage. The intima-media thickness of the common carotid artery (C-IMT) is an established measure of early atherosclerotic changes and is used as a surrogate end points of vascular outcomes in clinical trials $[42,43]$. This parameter is included in European guidelines on prevention of cardio-vascular disorders. Threshold value for IMT is considered to be $0.9 \mathrm{~mm}$. An increase in IMT over threshold value indicates progression of atherosclerosis. Similar to the classical risk factors such as diabetes, hyperlipidemia and obesity, this is an independent risk factor for CHD. Positive correlation has been reported between coronary artery IMT and degree of atherosclerotic changes [44]. Measurement of the carotid artery 
Unsal et al. Journal of Medical Disorders 2014,

intima-media thickness (CIMT) via B-mode ultrasonography provides easy evaluation of atherosclerosis. In the present study, CIMT measurement was not different in the $\mathrm{SCH}$ group as compared to the control group. However, CIMT decreased after levothyroxine replacement in the $\mathrm{SCH}$ group and this was statistically significant. The results from the present study show that subclinical hypothroidism is associated with elevated cardiovascular risk as assessed by CIMT.

In $\mathrm{SCH}$, left ventricle relaxation time shortens, vascular tonus increases, and left ventricle systolic dysfunction and endothelial dysfunction occurs with exercise. There are some studies that demonstrate improvement in cardiac contractility and systolic time interval with levothyroxine therapy [45]. However, there is no evidence supporting the relation between a serum TSH level below $10 \mathrm{mIU} / \mathrm{L}$ and heart failure. Many studies have evaluated the patients with a serum TSH concentration higher than $10 \mathrm{mIU} / \mathrm{L}$. Therefore, the results that strongly suggest the presence of relation for TSH concentration higher than $10 \mathrm{mIU} / \mathrm{L}$ would be insufficient for TSH concentration less than $10 \mathrm{mIU} / \mathrm{L}$. Benefit of levothyroxine therapy could not be demonstrated in a study in which TSH concentration was 5-10 mIU/L [46]. In the present study, CIMT was higher in the group with TSH concentration higher than $7 \mathrm{IU} / \mathrm{mL}$; but this was not statistically significant. The number of subjects participating in this study was small and the design was not placebo-controlled. Spectrum of TSH levels in SCH should be confirmed by larger randomized studies.

Several factors such as body mass index, fat distribution, lipid profile, and vascular dysfunction may contribute to $\mathrm{CV}$ risk in $\mathrm{SCH}$. Population-based studies demonstrated a relation between $\mathrm{Ml}$, aortic sclerosis and $\mathrm{SCH}$ in elder women independent from serum cholesterol concentration [27]. Nevertheless, Soo-Kyung KIM et al., stated that decrease in CIMT might be due to improvement in atherogenic lipid profile (LDL-cholesterol in particular) with thyroid hormone replacement [33]. In the present study as well, however, decrease in CIMT with levothyroxine therapy independent from LDL cholesterol level in $\mathrm{SCH}$ patients was found to be statistically significant.

Enlargement of the thyroid gland is due to several factors, such as hormonal or immunogical stimulation, inflammatory, proliferative, infiltrative, or metabolic disorders. It is thought that many factors (GSF, Growth Stimulating Factor) that leads to development of non-toxic goiter are important causes of enhancement in follicular cell replication. These factors arise from either systemic circulation (endocrine) or thyroid follicular or stromal cells (autocrine or paracrine effect). Thyrotropin (TSH) is the main extrathyroid GSF of thyroid $[47,48]$. Endogen TSH stimulation has been shown to increase thyroid gland size. Moreover, thyroid volume was found to be associated with age, height, weight, body surface area, iodine status, hyperinsulinemia, and luteinizing hormone (LH) [30]. Hegedus et al., reported that the difference between males and females in terms of the mean thyroid gland volume is significant and correlated with body weight and age [49].
Ueda found thyroid gland volume to be correlated with age, height, weight and body surface area with no difference found between males and females [50]. In the present study, no difference was determined between the patients with $\mathrm{SCH}$ and the control group in terms of thyroid volume. This might be associated with higher number of female patients in the $\mathrm{SCH}$ group versus the control group. However, thyroid volume statistically significantly decreased after levothyroxine therapy in $\mathrm{SCH}$ individuals. Although there is no cut-off value for TSH level on this subject, there was no statistically significant difference when the patients with serum TSH level less than $7 \mathrm{ulU} / \mathrm{mL}$ and higher than $7 \mathrm{ulU} / \mathrm{mL}$ (because the mean TSH was $6.77 \pm 2.902$ in the $\mathrm{SCH}$ group) were compared; but thyroid volume was found to be higher in the group with TSH level higher than $7 \mathrm{ulU} / \mathrm{mL}$.

Limitation of this study is that we did not placebo-controlled. Also, Female patients in $\mathrm{SCH}$ group was more than control group. Thus, the changes in IMT and thyroid volume could be related to the gender (Table 3 ).

Table 3. Changes of CIMT and thyroid volume in patient groups according to different TSH level.

\begin{tabular}{lllc}
\hline & TSH $<7 \mathrm{uIU} / \mathrm{ml}$ & $\mathrm{TSH} \geq 7 \mathrm{uIU} / \mathrm{ml}$ & $\boldsymbol{p}$ \\
\hline $\begin{array}{l}\text { C-intima media } \\
\text { thickness (mm) }\end{array}$ & $0.52 \pm 0.10$ & $0.56 \pm 0.13$ & 0.427 \\
Thyroid volume (ml) & $11.15 \pm 4.82$ & $12.15 \pm 4.26$ & 0.196 \\
\hline
\end{tabular}

Data are the mean \pm SD

In conclusion, our study showed the reduction in CIMT with L-thyroxin therapy in the patients with subclinical hypothyroidism. Early stage atherosclerosis are encountered also in the hypothyroidism. $\mathrm{SCH}$ and hypothyroidism may have adverse effects on endothelial function independently of other well-known atherosclerotic risk factors. Thyroid hormone replacement might help to slow down or prevent atherosclerosis in the subclinical hypothyroidism as well. Therefore, patients with subclinical hypothyroidism should be treated same as hypothyroidism. CIMT is an important marker for atherosclerosis; but long-term and placebo-controlled studies that would evaluate benefit of thyroid hormone replacement on cardiovascular events and mortality in $\mathrm{SCH}$ are needed.

\section{List of abbreviations}

SCH: Subclinical hypothyroidism

TSH: Thyroid stimulating hormone

CIMT: Carotid artery intima-media thickness

CVD: Cardiovascular disease

HDL-C: High density lipoprotein cholesterol

LDL-C: Low density lipoprotein cholesterol

\section{Competing interests}

The authors declare that they have no competing interests. 
Unsal et al. Journal of Medical Disorders 2014,

http://www.hoajonline.com/journals/pdf/2053-3659-2-1.pdf

doi: 10.7243/2053-3659-2-1

Authors' contributions

\begin{tabular}{|l|c|c|c|c|c|c|c|c|c|c|c|c|c|c|}
\hline Authors' contributions & I O & OT & EC & NC & BK & AG & MS & ET & BU & TD & MK & MC & EC & TD \\
\hline Research concept and design & $\checkmark$ & -- & -- & -- & -- & -- & -- & -- & -- & -- & -- & -- & $\checkmark$ & $\checkmark$ \\
\hline Collection and/or assembly of data & $\checkmark$ & $\checkmark$ & $\checkmark$ & $\checkmark$ & $\checkmark$ & $\checkmark$ & $\checkmark$ & $\checkmark$ & $\checkmark$ & $\checkmark$ & $\checkmark$ & $\checkmark$ & $\checkmark$ & $\checkmark$ \\
\hline Data analysis and interpretation & $\checkmark$ & -- & -- & -- & -- & -- & -- & -- & -- & -- & -- & -- & $\checkmark$ & $\checkmark$ \\
\hline Writing the article & $\checkmark$ & -- & -- & -- & -- & -- & -- & -- & -- & -- & -- & -- & -- & -- \\
\hline Critical revision of the article & $\checkmark$ & -- & -- & -- & -- & -- & -- & -- & -- & -- & -- & -- & -- & -- \\
\hline Final approval of article & $\checkmark$ & $\checkmark$ & $\checkmark$ & $\checkmark$ & $\checkmark$ & $\checkmark$ & $\checkmark$ & $\checkmark$ & $\checkmark$ & $\checkmark$ & $\checkmark$ & $\checkmark$ & $\checkmark$ & $\checkmark$ \\
\hline Statistical analysis & $\checkmark$ & -- & -- & -- & -- & -- & -- & -- & -- & -- & -- & -- & $\checkmark$ & -- \\
\hline
\end{tabular}

\section{Publication history}

Senior Editor: Wei Xin, Capital Medical University, China.

Editors: Raffaele Izzo, Federico II University Hospital, Italy.

Shiwei Duan, Ningbo University, China.

Received: 04-Jul-2014 Final Revised: 25-Jul-2014

Accepted: 01-Aug-2014 Published: 13-Aug-2014

\section{References}

1. Cooper DS. Clinical practice. Subclinical hypothyroidism. N Engl J Med. 2001; 345:260-5. I Article I PubMed

2. Hollowell JG, Staehling NW, Flanders WD, Hannon WH, Gunter EW, Spencer CA and Braverman LE. Serum TSH, T(4), and thyroid antibodies in the United States population (1988 to 1994): National Health and Nutrition Examination Survey (NHANES III). J Clin Endocrinol Metab. 2002; 87:489-99. | Article | PubMed

3. Canaris GJ, Manowitz NR, Mayor G and Ridgway EC. The Colorado thyroid disease prevalence study. Arch Intern Med. 2000; 160:526-34. Article I PubMed

4. Sawin CT, Chopra D, Azizi F, Mannix JE and Bacharach P. The aging thyroid. Increased prevalence of elevated serum thyrotropin levels in the elderly. JAMA. 1979; 242:247-50. | Article I PubMed

5. Tunbridge WM, Evered DC, Hall R, Appleton D, Brewis M, Clark F, Evans $J G$, Young E, Bird T and Smith PA. The spectrum of thyroid disease in a community: the Whickham survey. Clin Endocrinol (Oxf). 1977; 7:48193. | Article | PubMed

6. Parle JV, Franklyn JA, Cross KW, Jones SC and Sheppard MC. Prevalence and follow-up of abnormal thyrotrophin (TSH) concentrations in the elderly in the United Kingdom. Clin Endocrinol (Oxf). 1991; 34:77-83. I PubMed

7. Lindeman RD, Schade DS, LaRue A, Romero LJ, Liang HC, Baumgartner RN, Koehler KM and Garry PJ. Subclinical hypothyroidism in a biethnic, urban community. J Am Geriatr Soc. 1999; 47:703-9. I Article I PubMed

8. Bemben DA, Winn P, Hamm RM, Morgan L, Davis A and Barton E. Thyroid disease in the elderly. Part 1. Prevalence of undiagnosed hypothyroidism. J Fam Pract. 1994; 38:577-82. I PubMed

9. Bagchi N, Brown TR and Parish RF. Thyroid dysfunction in adults over age $\mathbf{5 5}$ years. A study in an urban US community. Arch Intern Med. 1990; 150:785-7. | Article | PubMed

10. Biondi B and Cooper DS. The clinical significance of subclinical thyroid dysfunction. Endocr Rev. 2008; 29:76-131. I Article I PubMed

11. Ayala AR, Danese MD and Ladenson PW. When to treat mild hypothyroidism. Endocrinol Metab Clin North Am. 2000; 29:399-415. I Article

12. Caraccio N, Dardano A, Manfredonia F, Manca L, Pasquali L, ludice A, Murri L, Ferrannini E and Monzani F. Long-term follow-up of 106 multiple sclerosis patients undergoing interferon-beta $1 \mathrm{a}$ or $1 \mathrm{~b}$ therapy: predictive factors of thyroid disease development and duration. J Clin Endocrinol Metab. 2005; 90:4133-7. I Article I PubMed

13. Singer P. Primary hypothyroidism due to other causes. In: Braverman LE,
Utiger RD, eds. Werner, Ingbar's the thyroid: a fundamental and clinical text. $\mathbf{8}^{\text {th }}$ ed. Philadelphia: Lippincott, Williams \& Wilkins; 2005; 745-754.

14. Hancock SL, Cox RS and McDougall IR. Thyroid diseases after treatment of Hodgkin's disease. N Engl J Med. 1991; 325:599-605. | Article | PubMed

15. Anker GB, Lonning PE, Aakvaag A and Lien EA. Thyroid function in postmenopausal breast cancer patients treated with tamoxifen. Scand J Clin Lab Invest. 1998; 58:103-7. I PubMed

16. Kumar N, Allen KA, Riccardi D, Bercu BB, Cantor A, Minton S, Balducci $L$ and Jacobsen PB. Fatigue, weight gain, lethargy and amenorrhea in breast cancer patients on chemotherapy: is subclinical hypothyroidism the culprit? Breast Cancer Res Treat. 2004; 83:149-59. | Article | PubMed

17. Basaria S, Cooper DS. Amiodarone and the thyroid. AmJ Med. 2005; 118:706-714. | Article | PubMed

18. Zhang ZJ, Qiang Li, Kang WH, Tan QR, Gao CG, Zhang FG, Wang HH, Ma XC, Ce Chen, Wei Wang, Li Guo, Zhang YH, Yang XB, Zhang RG.Differences in hypothyroidism between lithium-free and-treated patients with bipolar disorders. Life Sci. 2006; 78: 771-776. I Article I PubMed

19. Lazarus JH. The effects of lithium therapy on thyroid and thyrotropinreleasing hormone. Thyroid. 1998; 8:909-13. | Article | PubMed

20. Kleiner J, Altshuler L, Hendrick V and Hershman JM. Lithium-induced subclinical hypothyroidism: review of the literature and guidelines for treatment. J Clin Psychiatry. 1999; 60:249-55. I Article I PubMed

21. Carella C, Mazziotti G, Amato G, Braverman LE and Roti E. Clinical review 169: Interferon-alpha-related thyroid disease: pathophysiological, epidemiological, and clinical aspects. J Clin Endocrinol Metab. 2004; 89:3656-61. | Article | PubMed

22. Tonacchera M, Agretti P, De Marco G, Perri A, Pinchera A, Vitti P and Chiovato $\mathrm{L}$. Thyroid resistance to TSH complicated by autoimmune thyroiditis. J Clin Endocrinol Metab. 2001; 86:4543-6. | Article I PubMed

23. Alberti L, Proverbio MC, Costagliola S, Romoli R, Boldrighini B, Vigone MC, Weber G, Chiumello G, Beck-Peccoz P and Persani L. Germline mutations of TSH receptor gene as cause of nonautoimmune subclinical hypothyroidism. J Clin Endocrinol Metab. 2002; 87:2549-55. | Article | PubMed

24. Cappola AR, Fried LP, Arnold AM, Danese MD, Kuller LH, Burke GL, Tracy RP and Ladenson PW. Thyroid status, cardiovascular risk, and mortality in older adults. JAMA. 2006; 295:1033-41. | Article | PubMed Abstract | PubMed Full Text

25. Rodondi N, Newman AB, Vittinghoff E, de Rekeneire N, Satterfield S, Harris TB and Bauer DC. Subclinical hypothyroidism and the risk of heart failure, other cardiovascular events, and death. Arch Intern Med. 2005; 165:2460-6. | Article | PubMed

26. Razvi S, Shakoor A, Vanderpump M, Weaver JU and Pearce SH. The influence of age on the relationship between subclinical hypothyroidism and ischemic heart disease: a metaanalysis. J Clin Endocrinol Metab. 2008; 93:2998-3007. I Article I PubMed

27. Razvi S, Ingoe L, Keeka G, Oates C, McMillan C and Weaver JU. The beneficial effect of L-thyroxine on cardiovascular risk factors, endothelial function, and quality of life in subclinical hypothyroidism: 
Unsal et al. Journal of Medical Disorders 2014,

http://www.hoajonline.com/journals/pdf/2053-3659-2-1.pdf

randomized, crossover trial. J Clin Endocrinol Metab. 2007; 92:1715-23. | Article | PubMed

28. Monzani F, Caraccio N, Kozakowa M, Dardano A, Vittone F, Virdis A, Taddei S, Palombo $C$ and Ferrannini E. Effect of levothyroxine replacement on lipid profile and intima-media thickness in subclinical hypothyroidism: a double-blind, placebo- controlled study. J Clin Endocrinol Metab. 2004; 89:2099-106. | Article | PubMed

29. Servet Şeker and İsmet Taş. Determination of Thyroid Volume and Its Relation with Isthmus Thickness. Eur J Gen Med. 2010; 7:125-129. | Pdf

30. Cakir E, Sahin M, Topaloglu O, Colak NB, Karbek B, Gungunes A, Arslan MS, Unsal IO, Tutal E, Ucan B and Delibasi T. The relationship between LH and thyroid volume in patients with PCOS. J Ovarian Res. 2012; 5:43. | Article | PubMed Abstract | PubMed Full Text

31. Hak AE, Pols HA, Visser TJ, Drexhage HA, Hofman A and Witteman JC. Subclinical hypothyroidism is an independent risk factor for atherosclerosis and myocardial infarction in elderly women: the Rotterdam Study. Ann Intern Med. 2000; 132:270-8. | Article I PubMed

32. Walsh JP, Bremner AP, Bulsara MK, O'Leary P, Leedman PJ, Feddema P and Michelangeli V. Subclinical thyroid dysfunction as a risk factor for cardiovascular disease. Arch Intern Med. 2005; 165:2467-72. | Article | PubMed

33. Kim SK, Kim SH, Park KS, Park SW and Cho YW. Regression of the increased common carotid artery-intima media thickness in subclinical hypothyroidism after thyroid hormone replacement. Endocr J. 2009; 56:753-8. | Article | PubMed

34. Chiche F, Jublanc C, Coudert M, Carreau V, Kahn JF and Bruckert E. Hypothyroidism is not associated with increased carotid atherosclerosis when cardiovascular risk factors are accounted for in hyperlipidemic patients. Atherosclerosis. 2009; 203:269-76. | Article | PubMed

35. Vanderpump MP, Tunbridge WM, French JM, Appleton D, Bates D, Clark F, Grimley Evans J, Rodgers H, Tunbridge F and Young ET. The development of ischemic heart disease in relation to autoimmune thyroid disease in a 20-year follow-up study of an English community. Thyroid. 1996; 6:155-60. | PubMed

36. Rodondi N, Aujesky D, Vittinghoff E, Cornuz J and Bauer DC. Subclinical hypothyroidism and the risk of coronary heart disease: a meta-analysis. Am J Med. 2006; 119:541-51. | Article | PubMed

37. Ochs N, Auer R, Bauer DC, Nanchen D, Gussekloo J, Cornuz J and Rodondi N. Meta-analysis: subclinical thyroid dysfunction and the risk for coronary heart disease and mortality. Ann Intern Med. 2008; 148:83245. | Article | PubMed

38. Singh S, Duggal J, Molnar J, Maldonado F, Barsano CP and Arora R. Impact of subclinical thyroid disorders on coronary heart disease, cardiovascular and all-cause mortality: a meta-analysis. Int J Cardiol. 2008; 125:41-8. | Article | PubMed

39. Haentjens P, Van Meerhaeghe A, Poppe K and Velkeniers B. Subclinical thyroid dysfunction and mortality: an estimate of relative and absolute excess all-cause mortality based on time-to-event data from cohort studies. Eur J Endocrinol. 2008; 159:329-41. I Article I PubMed

40. Milionis HJ, Tambaki AP, Kanioglou CN, Elisaf MS, Tselepis AD and Tsatsoulis A. Thyroid substitution therapy induces high-density lipoprotein-associated platelet-activating factor-acetylhydrolase in patients with subclinical hypothyroidism: a potential antiatherogenic effect. Thyroid. 2005; 15:455-60. | Article | PubMed

41. Taddei S, Caraccio N, Virdis A, Dardano A, Versari D, Ghiadoni L, Salvetti A, Ferrannini E and Monzani F. Impaired endothelium-dependent vasodilatation in subclinical hypothyroidism: beneficial effect of levothyroxine therapy. J Clin Endocrinol Metab. 2003; 88:3731-7. I Article I PubMed

42. O'Leary DH and Polak JF. Intima-media thickness: a tool for atherosclerosis imaging and event prediction. Am J Cardiol. 2002; 90:18L-21L. | Article | PubMed

43. Bots ML, Hoes AW, Koudstaal PJ, Hofman A and Grobbee DE. Common carotid intima-media thickness and risk of stroke and myocardial infarction: the Rotterdam Study. Circulation. 1997; 96:1432-7. | Article I PubMed

44. Knapp M, Lisowska A, Sobkowicz B, Tycinska A, Sawicki R and Musial
WJ. Myocardial perfusion and intima-media thickness in patients with subclinical hypothyroidism. Adv Med Sci. 2013; 58:44-9. | Article | PubMed

45. Fatourechi V. Subclinical hypothyroidism: an update for primary care physicians. Mayo Clin Proc. 2009; 84:65-71. | Article I PubMed Abstract I PubMed Full Text

46. Kong WM, Sheikh MH, Lumb PJ, Naoumova RP, Freedman DB, Crook M, Dore $\mathrm{CJ}$ and Finer N. A 6-month randomized trial of thyroxine treatment in women with mild subclinical hypothyroidism. Am J Med. 2002; 112:348-54 | Article | PubMed

47. Dumont JE, Maenhaut C, Pirson I, Baptist M and Roger PP. Growth factors controlling the thyroid gland. Baillieres Clin Endocrinol Metab. 1991; 5:727-54. | Article | PubMed

48. Dumont JE, Lamy F, Roger P and Maenhaut C. Physiological and pathological regulation of thyroid cell proliferation and differentiation by thyrotropin and other factors. Physiol Rev. 1992; 72:667-97. | Article I PubMed

49. Hegedus L, Perrild $H$ and Poulsen LR et al. The determination of thyroid volüme by ultrasound and its relationship to body weight, age, and sex in normal subjects. J Clin Endocrinol Metab. 1983; 56:2. | Article

50. Ueda D. Sonographic measurement of the volume of the thyroid gland in healthy children. Acta Paediatr Jpn. 1989; 31:352-4. | Article | PubMed

\section{Citation:}

Unsal IO, Topaloglu O, Cakir E, Bozkurt NC, Karbek B, Gungunes A, Arslan MS, Akkaymak ET, Ucan B, Demirci T, Karakose M, Caliskan M, Cakal E and Delibasi T. Effect of L-thyroxin therapy on thyroid volume and carotid artery lntima-media thickness in the patients with subclinical hypothyroidism.

J Med Disord. 2014; 2:1. http://dx.doi.org/10.7243/2053-3659-2-1 